\title{
PROFESIONALNO IZGARANJE I TJELESNA AKTIVNOST ODGOJITELJICA U DJEČJEM VRTIĆU JARUN
}

UDK 373.24.08:613.7

PRIMLJENO: 8.1.2020.

PRIHVAĆENO: 26.10 .2020

Ovo djelo je dano na korištenje pod Creative Commons Attribution 4.0 International License

SAŽETAK: Današnja istraživanja koja se bave stresom odgojitelja na radnom mjestu su rjeđa u odnosu na istraživanja koja uključuju stres učitelja i nastavnika. Odgojitelji u dječjem vrtiću su u stalnom kontaktu s djecom i rade iznimno odgovoran posao. Stoga je ovo istraživanje opravdano u cilju utvrđivanja intenziteta izgaranja i razine tjelesne aktivnosti te prevencije pojava negativnih reakcija. Cilj rada je tvrditi razinu tjelesne aktivnosti, intenzitet izgaranja na poslu, ukupnu razinu stresa na poslu te razinu zadovoljstva životom odgojiteljica zaposlenih u Dječjem vrtiću Jarun te ispitati povezanost navedenih varijabli. U ispitivanju je sudjelovalo 80 odgojiteljica predškolske djece u dobi od 23 do 61 godine. Uzorak je obuhvatio 95 \% odgojiteljica zaposlenih u Dječjem vrtiću Jarun, drugom po veličini vrtiću u Gradu Zagrebu. Istraživanje je provedeno putem pet upitnika s ukupno 76 pitanja: Sociodemografski upitnik, Upitnik intenziteta sagorijevanja na poslu, Skala procjene stresnosti posla odgojitelja, Međunarodni upitnik o tjelesnoj aktivnosti i Skala procjene zadovoljstva životom. Statistička obrada prikazana je putem osnovnih deskriptivnih pokazatelja (uključujući Kolmogorov-Smirnovljev test normaliteta distribucije i Box and Whisker dijagram) te distribucije uzorka po referentnim intervalima pojedinih mjernih instrumenata. Povezanost između glavnih varijabli testirana je serijom linearnih bivarijatnih regresijskih analiza. Istraživanje je pokazalo da odgojiteljice zaposlene u Dječjem vrtiću Jarun imaju visoku razinu tjelesne aktivnosti, svoj posao ukupno doživljavaju umjereno stresnim, imaju mali intenzitet izgaranja na poslu te su u prosjeku malo zadovoljne životom. Odgojiteljice s ukupno višom razinom stresa na poslu imaju viši intenzitet izgaranja na poslu te su nezadovoljnije životom. Rezultati daju smjernice za preventivne mjere u redukciji profesionalnog stresa i edukaciju odgojiteljica usmjerenu na poticanje i održavanje njihove tjelesne aktivnosti na razini koja im pozitivno utječe na zdravlje.

Ključne riječi: djeca, predškolska dob, stres, tjelesno vježbanje, zadovoljstvo životom

\section{UVOD}

Zagreb ima 60 gradskih vrtića. Uz odgojitelje i ravnatelja, svaki gradski vrtić u Zagrebu ima i stručni tim (pedagog, psiholog, defektolog, logoped) te zdravstvenog voditelja - višu medicinsku sestru/medicinskog tehničara. Od počet-

*Marija Možnik, mag. med. techn., (marija.smjerog@gmail.com), Dječji vrtić Jarun, Bartolići 39A, 10000 Zagreb, osoba za kontakt: izv. prof. dr. sc. Milan Milošević, Medicinski fakultet Sveučilišta u Zagrebu Škola narodnog zdravlja „Andrija Štampar", Katedra za zdravstvenu ekologiju i medicinu rada i sporta, Rockefellerova 4, 10000 Zagreb, dr. sc. Marijo Možnik, Kineziološki fakultet Sveučilišta u Zagrebu, Zavod za kineziologiju sporta, Horvaćanski zavoj 15, 10000 Zagreb. ka rada dječjih vrtića u Gradu Zagrebu obvezno su zapošljavane glavne medicinske sestre (danas zdravstvene voditeljice), a zapošljavanje stručnih suradnika i ekipiranje stručno razvojne službe započelo je u 80-im godinama 20. stoljeća.

Dječji vrtić Jarun je - prema broju upisane djece $(\mathrm{N}=890)$, broju odgojitelja $(\mathrm{N}=85)$ i odgojnih skupina ( $N=39)$ - drugi po veličini u Gradu Zagrebu. Dječji vrtić Jarun radi na području naselja Jarun, Gajevo i Staglišće od prosinca 1978. godine, a uprava vrtića nalazi se na adresi Bartolići 39A. Danas je u vrtiću upisano 890 djece u dobi 
od 1 godine do polaska u školu. Djeca su smještena u 39 odgojnih skupina na 7 različitih lokacija. O zadovoljavanju dječjih potreba svakodnevno vodi brigu 136 zaposlenih djelatnika (95 stručnih djelatnika - odgojitelji i stručni suradnici, a ostalo je tehnička služba); (DV Jarun, 2019).

Glavna uloga medicinske sestre - zdravstvenog voditelja u vrtiću je da brine o zdravstvenoj zaštiti djece, pravilnoj prehrani u vrtiću, higijensko-sanitarnim uvjetima te da promiče sigurnu okolinu i zdravo okruženje u kojem djeca borave. Zdravstveni voditelj provodi propisane mjere zdravstvene zaštite djece u vrtiću prema Programu zdravstvene zaštite, higijene i prehrane djece te Zakonu o predškolskom odgoju.

S obzirom da su odgojitelji cjelodnevno u kontaktu s djecom, važno je brinuti i o njihovom zdravlju te ih kontinuirano educirati o zdravim navikama jer to indirektno utječe na njihov odnos s djecom. U tom smislu poželjno je da su odgojitelji što boljeg mentalnog i fizičkog zdravlja, a jedan od dostupnih i bitnih čimbenika koji pozitivno utječu na mentalno i fizičko zdravlje je tjelesna aktivnost. Pretraživanjem dostupne literature ne nalaze se istraživanja povezana s tjelesnom aktivnosti odgojitelja predškolske djece.

\section{STRES}

Sauter i Murphy (1998.) definiraju stanje stresa na poslu kao niz, za pojedinca, štetnih fizioloških, psiholoških i bihevioralnih reakcija na situacije u kojima zahtjevi posla nisu u skladu s njegovim sposobnostima, mogućnostima i potrebama. Stres na poslu može dovesti do lošeg zdravlja pa čak i do ozljede.

Havelka (1998.) stresore dijeli na: fizičke (izloženost jakoj buci, vrućini ili hladnoći, prirodne nepogode i katastrofe), psihološke (izloženost raznim međuljudskim sukobima, u obitelji, na poslu, neuspjesi, psihološki konflikti i frustracije), socijalne (izloženost velikim socijalnim promjenama, ekonomskim krizama, ratovima, naglim promjenama društvenih odnosa). Ova podjela ukazuje da su odgojitelji u dječjem vrtiću izloženi djelovanju sve tri vrste stresora. Buka i vika su neizostavan dio dječjeg života i to je najčešći fizički stresor koji je prisutan u poslu odgojitelja. Kada buka prijeđe prag tolerancije odgojitelja, može biti veliki stresor i za njihovo mentalno zdravlje. Stalni međusobni sukobi djece mogu se navesti kao jedan od najčešćih psiholoških stresora jer se odgojitelji s time najčešće susreću. U starijim skupinama odgojitelji moraju često rješavati konflikte među djecom, ali isto tako i konflikte između odgojitelja, odnosno svojih kolega. Veliki psihološki stres odgojiteljima može stvarati pritisak od strane uprave vrtića ili potencijalno neugodne situacije s roditeljima, odnosno nepoštovanje odgojiteljske struke kada se na njihov posao gleda iz perspektive da to može raditi bilo tko, bez potrebnog obrazovanja. Socijalni pritisak u vrtiću manifestira se kroz izloženost raznim promjenama u obrazovanju pa je tako danas za rad u vrtiću u ulozi odgojitelja potrebno završiti stručno obrazovanje za predškolski odgoj. Niske plaće ili ekonomska kriza također mogu biti jedan od socijalnih stresora odgojiteljima.

\section{Profesionalno izgaranje}

Profesionalno izgaranje temelji se na modelu koji polazi od toga da su posljedice duge izloženosti stresu na poslu emocionalna iscrpljenost, depersonalizacija drugih i značajno snižena percepcija osobnog postignuća koje se onda posebno i mjere (Tatalović Vorkapić, Lončarić, 2013.). Do emocionalne iscrpljenosti dolazi zbog kontakta s drugim ljudima, a ona se odnosi na osjećaj nesposobnosti emocionalnog angažmana i davanja u interakciji s drugima. Kad se previše psihički i emocionalno iscrpi, čovjek se osjeća "potrošenim" i više nije sposoban normalno funkcionirati na emocionalnoj razini. Još jedna od posljedica iscrpljenosti je i bezosjećajnost prema poslu i kolegama, što može prijeći u konflikte, grubost, neosjetljivost i cinizam. Stresni uvjeti na poslu mogu dovesti do brojnih negativnih posljedica kod pojedinaca, kao što su iscrpljenost, profesionalno izgaranje, opadanje u radnom učinku te do drugih zdravstvenih problema kao što su pretjerano konzumiranje alkohola, kofeina, pušenja, preskakanje obroka i dr. (Cooper et al., 2001.).

\section{Odgojiteljski stres}

Odgojiteljski posao je vrlo specifičan jer su svakodnevno izloženi višestrukim interakcijama i odnosima, kako s djecom različite dobi, tako 
i s odraslima (kolege, roditelji, nadređeni). Odgojiteljski poziv pretpostavlja integraciju važnih ciljeva kao što su promicanje razvoja djeteta, zadovoljavanje potreba djeteta, pružanje ljubavi i nježnosti, briga i discipliniranje djece (ClarkeStewart, 1993.). Odgojitelji se moraju uz kurikularne promjene u radu prilagođavati prvenstveno individualnim potrebama djece (Kelly, Berthelsen, 1995.).

Živčić-Bećirević i Smojver-Ažić (2005.) zaključuju putem primjene analize sadržaja i metode dnevnika na temelju iskaza nekoliko odgojitelja da su dodatni stresori koji se stalno nameću odgojiteljima vremenski pritisak, zadovoljenje potreba djece i osobnih potreba, suočavanje s poslovima koji nisu u njihovoj kompetenciji, interakcija s roditeljima djece te stalne prilagodbe na nove promjene u predškolskom kurikulumu.

Činjenica da je odgojiteljska uloga osjetljiva i kompleksna daje nam uvid u razumijevanje koliko je taj posao stresan. Pogreške učinjene u ranom i predškolskom odgoju i obrazovanju mogu imati dalekosežne posljedice te biti prepreka daljnjem napredovanju djece. S druge strane, kompleksnost odgojiteljskog posla ističe se u činjenici da svaki odgojitelj mora planirati i organizirati rad s djecom, razvijati njihove sposobnosti i poticati razvoj kognitivnih, emocionalnih i socijalnih kompetencija. S vremenom odgojiteljski posao postaje sve zahtjevniji i kompleksniji zbog razvoja predškolske pedagogije, dječje psihologije i metodike. Odgojitelj mora biti u toku te stalno pratiti i poznavati sve promjene u odgojno-obrazovnom sustavu, adekvatno ih primijeniti i evaluirati, a to se dodatno odražava i na složenost njihova posla.

\section{Tjelesna aktivnost}

Tjelesnom aktivnošću definira se svaki pokret tijela koji je izveden aktivacijom skeletnih mišića, a rezultira potrošnjom energije (Caspersen et al., 1985.). Tjelesnu aktivnost je, također, definirala Svjetska zdravstvena organizacija (SZO) prema kojoj tjelesna aktivnost obuhvaća sve pokrete, tj. kretanje u svakodnevnom životu, uključujući posao, transport, kućanske poslove, rekreaciju i sportske aktivnosti, a kategorizirana je prema razini intenziteta, od niskog preko umjerenog, do snažnog tj. visokog intenziteta (World Health Organization, 2006.). Tako definirana tjelesna ak- tivnost najčešće se promatra kroz četiri osnovne kategorije/područja:

a) tjelesna aktivnost na poslu;

b) tjelesna aktivnost povezana s prijevozom, tj. putovanjem s mjesta na mjesto;

c) tjelesna aktivnost u kućanstvu;

d) tjelesna aktivnost u slobodnom vremenu.

Mišigoj-Duraković i suradnici (2007.) navode rezultate hrvatske zdravstvene ankete iz 2003. g. koji upućuju da 35,8\% odrasle populacije (oko 44 \% muškaraca i 30 \% žena) nije dovoljno tjelesno aktivno, i to prema kriteriju od 30 minuta umjerene tjelesne aktivnosti dnevno. Također zabrinjavajući je podatak da je najniža razina tjelesne aktivnosti (42,7 MET-sati/tjedan) utvrđena u skupini mladih od 15 do 24 godine Jurakić et al., 2009.). Analizirajući razinu tjelesne aktivnosti u Republici Hrvatskoj, rezultati pokazuju da se oko $60 \%$ odrasle populacije ne bavi nikakvim tjelesnim vježbanjem, razina tjelesne aktivnosti u područjima transporta i slobodnoga vremena vrlo je niska, a značajno najveća tjelesna neaktivnost tijekom slobodnog vremena zabilježena je u odraslih zagrebačkih muškaraca (88,6 \%); (Heimer et al., 2011.).

U ovom radu istražit će se povezanost razine tjelesne aktivnosti sa sljedećim varijablama: intenzitet izgaranja na poslu, ukupna razina stresa na poslu te razina zadovoljstva životom odgojiteljica predškolske djece. Dobiveni rezultati dat će značajan doprinos za odgojiteljsku profesiju u smislu određivanja smjernica za unapređenje zdravstvenog stanja odgojitelja, a samim time i odgojno-obrazovne prakse ranog i predškolskog odgoja. Ovo istraživanje ima i praktičan doprinos jer će se na temelju dobivenih rezultata dobiti konkretan uvid u stanje drugog po veličini vrtića u Gradu Zagrebu.

\section{CILJ ISTRAŽIVANJA}

Cilj 1: Utvrditi razinu tjelesne aktivnosti, intenzitet izgaranja na poslu, ukupnu razinu stresa na poslu odgojitelja te razinu zadovoljstva životom u 80 odgojiteljica.

Cilj 2: Ispitati povezanost razine tjelesne aktivnosti sa sljedećim varijablama: intenzitet iz- 
garanja na poslu; ukupna razina stresa na poslu odgojitelja; razina zadovoljstva životom.

Cilj 3: Ispitati povezanost razine stresa na poslu odgojitelja sa sljedećim varijablama: intenzitet izgaranja na poslu; zadovoljstvo životom.

\section{METODOLOGIJA ISTRAŽIVANJA}

\section{Ispitanici}

Istraživanje je provedeno u Dječjem vrtiću Jarun putem upitnika. Sve ispitanice bile su upoznate s ciljem istraživanja koje je bilo anonimno i dobrovoljno. $U$ ispitivanju je sudjelovalo 80 odgojiteljica predškolske djece u dobi od 23 do 61 godine. Uzorak čini 95 \% odgojiteljica zaposlenih u Dječjem vrtiću Jarun.

\section{Metoda istraživanja}

Istraživanje je provedeno tijekom lipnja 2019. godine putem pet upitnika s ukupno 76 pitanja. Ispitanice su potpisale suglasnost da pristaju na istraživanje te dobile detaljne upute i objašnjenje. Prije samog provođenja istraživanja ravnateljica vrtića zamoljena je za dopuštenje da se u vrtiću provede istraživanje. Uz uputu, sudionice su dobile informaciju da je sudjelovanje u istraživanju anonimno i dobrovoljno te da će se dobiveni podaci koristiti isključivo u znanstvene svrhe.

\section{Mjerni instrumenti}

Korišteni su sljedeći mjerni instrumenti:

- Upitnik sociodemografskih podataka

- Upitnik intenziteta sagorijevanja na poslu (Ajduković, Ajduković, 1994.)

- Skala procjene stresnosti posla odgojitelja (Klarin, Nenadić-Bilan, 2004.)

- Skraćena verzija Međunarodnog upitnika za procjenu razine tjelesne aktivnosti - International Physical Activity Questionnaire, Short Form (IPAQ-SF); (Craig et al., 2003.)
- Skala zadovoljstva životom, engl. Satisfaction With Life Scale (SWLS); (Diener et al., 1985.).

\section{REZULTATI}

Ukupni rezultati iskazani su na temelju odgovora 80 odgojiteljica zaposlenih u Dječjem vrtiću Jarun. Svi ispitanici su ženskog spola, prosječne dobi 46 godina $(S D=11,15)$. Ukupni radni staž odgojiteljica je 22,85 godine ( $\mathrm{SD}=12,29)$, a radni staž koji su provele u Dječjem vrtiću Jarun je 19,14 godina $(\mathrm{SD}=13,17)$.

Prosječna visina odgojiteljica je 166,42 cm $(\mathrm{SD}=6,8)$, a težina $69,92 \mathrm{~kg}(\mathrm{SD}=13,83)$. Vrijeme koje provedu na putovanju na posao je 30,36 minuta $(\mathrm{SD}=27,25)$, a u prosjeku imaju po jedno rođeno dijete $(\mathrm{SD}=1,02)$. Sociodemografski pokazatelji prikazani su u Tablici 1.

\section{Tablica 1. Sociodemografski pokazatelji}

Table 1. Sociodemographic indicators

\begin{tabular}{||l|c|c||}
\hline \multicolumn{1}{|c|}{ Varijabla } & AS & SD \\
\hline Dob (god) & 46 & 11,15 \\
\hline Trajanje radnog staža (god) & 22,85 & 12,29 \\
\hline $\begin{array}{l}\text { Trajanje radnog staža u DV Jarun } \\
\text { (god) }\end{array}$ & 19,14 & 13,17 \\
\hline Tjelesna visina (cm) & 166,42 & 6,80 \\
\hline Tjelesna masa (kg) & 69,92 & 13,83 \\
\hline $\begin{array}{l}\text { Vrijeme provedeno u putu na } \\
\text { posao (min) }\end{array}$ & 30,36 & 27,25 \\
\hline Broj djece & 1,25 & 1,02 \\
\hline
\end{tabular}

Legenda: AS-aritmetička sredina, SD-standardna devijacija

U Tablici 2 prikazani su podaci o obrazovanju, životu s partnerom i bolovanju odgojiteljica. Najviše odgojiteljica $(\mathrm{N}=66)$ ima višu stručnu spremu, dok ih srednju stručnu spremu i visoko obrazovanih ima po sedam. Velik broj mladih odgojiteljica trenutno se školuje na diplomskom studiju, odnosno nastavljaju s daljnjim školovanjem i obrazovanjem. Njih 48 živi s partnerom, a 
32 odgojiteljice ne žive s partnerom. Na bolovanju su u proteklih tjedan dana bile 4 odgojiteljice, dok je preostalih 76 odgojiteljica radilo.

\section{Tablica 2. Ostali relevantni podaci}

Table 2. Other relevant data

\begin{tabular}{||c|c|c||}
\hline Varijabla & Odgovor & N \\
\hline \multirow{3}{*}{ Stručna sprema } & SSS & 7 \\
\cline { 2 - 3 } & VŠS & 66 \\
\cline { 2 - 3 } & VSS & 7 \\
\hline \multirow{2}{*}{ Život s partnerom } & DA & 48 \\
\cline { 2 - 3 } & NE & 32 \\
\hline \multirow{2}{*}{$\begin{array}{l}\text { Bolovanje u } \\
\text { proteklih 7 dana }\end{array}$} & $\mathrm{DA}$ & 4 \\
\cline { 2 - 3 } & $\mathrm{NE}$ & 76 \\
\hline
\end{tabular}

Legenda: N-broj sudionica, SSS-srednja stručna sprema, VŠSviša škola/prvostupnica, VSS-visoka stručna sprema/diplomski studij

Osnovni deskriptivni pokazatelji prikazani su u Tablici 3. Razina tjelesne aktivnosti odgojiteljica u Dječjem vrtiću Jarun je 4743 MET-min/tjedno što ukazuje na visoku razinu tjelesne aktivnosti. Intenzitet izgaranja na poslu je 23,4 ( $\mathrm{SD}=4,6)$, što pokazuje da nemaju znakove izgaranja na poslu. Ukupna razina stresa na poslu prema Skali izvora stresa na poslu odgojitelja je 61,48 uz standardnu devijaciju 15,83, što znači da su u umjerenoj razini stresa koji doživljavaju na poslu. Zadovoljstvo životom odgojiteljica je u prosjeku 22,4 $(S D=6,56)$ što je pokazatelj da su malo zadovoljne životom.
Rezultati Kolmogorov-Smirnovljeva testa normaliteta distribucije vidljivi u Tablici 3 ne ukazuju na statistički značajna odstupanja od normalne distribucije što implicira da su sve varijable normalno distribuirane.

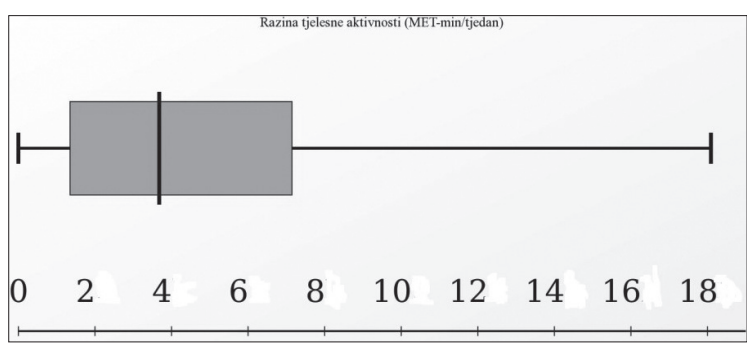

Slika 1. Box and Whisker dijagram za varijablu razine tjelesne aktivnosti (u tisućama MET-min/tjedan)

Figure 1. Box and Whisker Diagram for physical activity variable (in thousands MET-min/week)

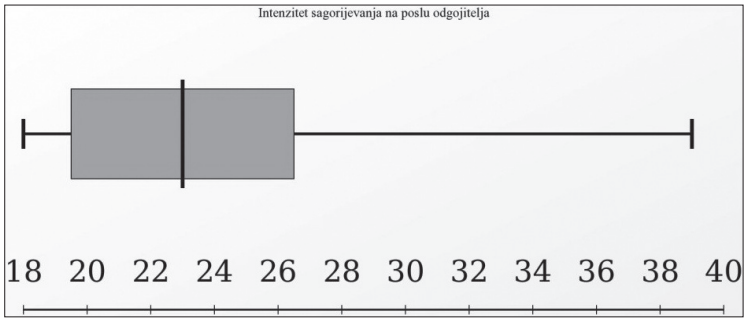

Slika 2. Box and Whisker dijagram za varijablu intenziteta izgaranja na poslu odgojitelja

Figure 2. Box and Whisker Diagram for burnout intensity variable for kindergarten teachers

\section{Tablica 3. Osnovni deskriptivni pokazatelji}

Table 3. Basic descriptive indicators

\begin{tabular}{||l|c|c|c|c|c|c|c||}
\hline \multicolumn{1}{|c|}{ Varijabla } & AS & SD & MED & MIN & MAX & K-S & p \\
\hline Razina tjelesne aktivnosti & 4743 & 4462 & 3679 & 0 & 18090 & 0,14 & 0,07 \\
\hline Intenzitet izgaranja na poslu & 23,4 & 4,60 & 23 & 18 & 39 & 0,11 & 0,19 \\
\hline Ukupna razina stresa na poslu odgojitelja & 61,48 & 15,83 & 63,5 & 17 & 94 & 0,11 & 0,24 \\
\hline Zadovoljstvo životom & 22,4 & 6,56 & 23 & 10 & 35 & 0,09 & 0,38 \\
\hline
\end{tabular}

Legenda: AS-aritmetička sredina, SD-standardna devijacija, MED-medijan, MIN-minimum, MAX-maksimum, K-S-Kolmogorov-Smirnovljev (D) test normaliteta distribucije, p-p-vrijednost K-S testa 


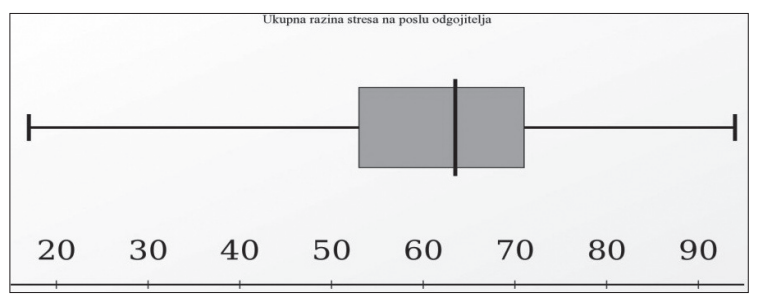

Slika 3. Box and Whisker dijagram za varijablu ukupne razine stresa na poslu odgojitelja

Figure 3. Box and Whisker Diagram for total stress level variable for kindergarten teachers

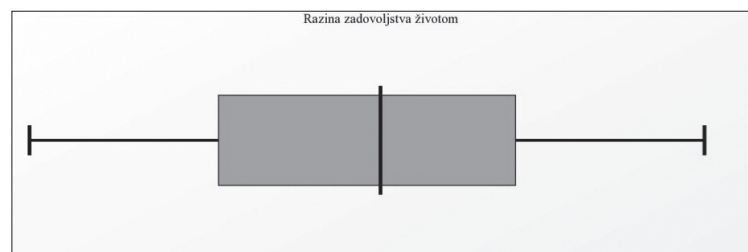

$\begin{array}{llllllllllllll}10 & 12 & 14 & 16 & 18 & 20 & 22 & 24 & 26 & 28 & 30 & 32 & 34 & 36\end{array}$

Slika 4. Box and Whisker dijagram za varijablu razine zadovoljstva životom

Figure 4. Box and Whisker Diagram for life satisfaction variable

Razina tjelesne aktivnosti je visoka jer je $53,75 \%$ odgojiteljica izjavilo da su u prosjeku sedam dana u tjednu kombinirale hodanje, umjereni intenzitet ili aktivnost visokog intenziteta te su postigle minimalnu ukupnu tjelesnu aktivnost od 3000 MET-min/tjedno, što je prikazano u Tablici 4. Njih $25 \%$ umjereno je aktivno, a nisku razinu tjelesne aktivnosti ima 21,25\% odgojiteljica zaposlenih u Dječjem vrtiću Jarun.

Tablica 4. Distribucija sudionica prema razini tjelesne aktivnosti (u MET-min/tjedno)

Table 4. Distribution of participants with regard to physical activity level (in MET-min/week)

\begin{tabular}{||l|c|c||}
\hline \multicolumn{1}{|c|}{ Razina tjelesne aktivnosti } & N & \% \\
\hline Niska (0-600) & 17 & 21,25 \\
\hline Umjerena (601-3000) & 20 & 25,00 \\
\hline Visoka (više od 3000) & 43 & 53,75 \\
\hline
\end{tabular}

Legenda: N-broj sudionica, \%-postotni udio
Prema rezultatima dobivenim na skali intenziteta izgaranja na poslu (Tablica 5) 73,75\% odgojiteljica ne pokazuje znakove izgaranja, a $26,25 \%$ odgojiteljica pokazuje početne znakove izgaranja.

Tablica 5. Distribucija sudionica prema intenzitetu izgaranja na poslu

Table 5. Distribution of participants with regard to burnout intensity at work

\begin{tabular}{||l|c|c||}
\hline \multicolumn{1}{|c|}{ Intenzitet izgaranja na poslu } & N & $\%$ \\
\hline Bez znakova izgaranja (18-25) & 59 & 73,75 \\
\hline Posebni znaci upozorenja (26-44) & 21 & 26,25 \\
\hline $\begin{array}{l}\text { Ozbiljno izgaranje; neophodna pomoć } \\
(45-54)\end{array}$ & 0 & 0 \\
\hline
\end{tabular}

Legenda: N-broj sudionica, \%-postotni udio

U Tablici 6 opisana je distribucija sudionica prema ukupnome stresu na poslu odgojitelja. Najviše ispitanica, njih 67,5\% ima umjerenu razinu stresa prema Skali izvora stresa na poslu odgojitelja, a 6,25 \% odgojiteljica izjavilo je da ne osjeća intenzivan stres na poslu, odnosno da imaju nisku razinu stresa, dok $26,25 \%$ odgojiteljica smatra da su pod visokom razinom stresa na poslu. Prosječna vrijednost samoprocjene stresnosti posla odgojitelja u sudionica ovoga istraživanja iznosi 2,27 (raspon 0-3).

Tablica 6. Distribucija sudionica prema ukupnome stresu na poslu odgojitelja

Table 6. Distribution of participants with regard to overall stress at work

\begin{tabular}{||c|c|c||}
\hline $\begin{array}{c}\text { Skala izvora stresa na poslu } \\
\text { odgojitelja (ukupna razina stresa) }\end{array}$ & N & \% \\
\hline Niska (0-35) & 5 & 6,25 \\
\hline Umjerena (36-70) & 54 & 67,5 \\
\hline Visoka (71-105) & 21 & 26,25 \\
\hline
\end{tabular}

Legenda: N-broj sudionica, \%-postotni udio 
Zadovoljstvo životom odgojiteljica opisano je u Tablici 7, a rezultati su pokazali da su u prosjeku prema bodovima malo zadovoljne životom. Sedam odgojiteljica je prema upitniku ekstremno zadovoljna životom, njih 23 su zadovoljne, malo zadovoljnih je 21, neutralno je njih 3, malo nezadovoljnih je 16 odgojiteljica, a nezadovoljstvo je iskazalo njih 10. lako je 28,75\% odgojiteljica dalo odgovor da je zadovoljno životom, aritmetička sredina pokazuje da su malo zadovoljne životom.

Tablica 7. Distribucija sudionica prema zadovoljstvu životom

Table 7. Distribution of participants with regard to life satisfaction

\begin{tabular}{||l|c|c||}
\hline \multicolumn{1}{|c|}{ Zadovoljstvo životom (SWLS) } & N & \% \\
\hline Ekstremno zadovoljna (31-35) & 7 & 8,75 \\
\hline Zadovoljna (26-30) & 23 & 28,75 \\
\hline Malo zadovoljna (21-25) & 21 & 26,25 \\
\hline Neutralna (20) & 3 & 3,75 \\
\hline Malo nezadovoljna (15-19) & 16 & 20,00 \\
\hline Nezadovoljna (10-14) & 10 & 12,50 \\
\hline Ekstremno nezadovoljna (5-9) & 0 & 0,00 \\
\hline
\end{tabular}

Legenda: N-broj sudionica, \%-postotni udio

Rezultati linearne bivarijatne regresijske analize (Tablica 8) ukazuju da u sudionica ovoga istraživanja nisu utvrđene statistički značajne povezanosti razine tjelesne aktivnosti s varijablama: intenzitet izgaranja na poslu; ukupna razina stresa na poslu odgojitelja; zadovoljstvo životom.
Tablica 8. Rezultati linearne bivarijatne regresijske analize za ispitivanje povezanosti razine tjelesne aktivnosti

Table 8. Results of linear bivariate regression analysis for investigating the relation of physical activity level

\begin{tabular}{||l|c|c|c||}
\hline \multirow{2}{*}{\multicolumn{1}{|c|}{ Varijabla }} & \multicolumn{2}{c||}{ Razina tjelesne aktivnosti } \\
\cline { 2 - 4 } & $\beta$ & $\mathrm{p}$ & $\mathrm{R}^{2}$ \\
\hline Intenzitet izgaranja na poslu & $-0,14$ & 0,21 & 0,02 \\
\hline $\begin{array}{l}\text { Ukupna razina stresa na } \\
\text { poslu odgojitelja }\end{array}$ & 0,11 & 0,31 & 0,01 \\
\hline \begin{tabular}{l} 
Zadovoljstvo životom \\
\hline
\end{tabular} & $-0,17$ & 0,12 & 0,03 \\
\hline
\end{tabular}

Legenda: $\beta$-standardizirani regresijski koeficijent, p-statistički značajna povezanost $(p<0,05), R^{2}$-proporcija varijance zavisne varijable objašnjena nezavisnom varijablom

Rezultati linearne bivarijatne regresijske analize (Tablica 9) ukazuju da sudionice s ukupno višom razinom stresa na poslu imaju statistički značajno viši intenzitet izgaranja na poslu te su statistički značajno nezadovoljnije životom.

Tablica 9. Rezultati linearne bivarijatne regresijske analize za ispitivanje povezanosti razine stresa na poslu odgojitelja

Table 9. Results of linear bivariate regression analysis for investigating the relation of stress at work for kindergarten teachers

\begin{tabular}{|c|c|c|c||}
\hline \multirow{2}{*}{ Varijabla } & \multicolumn{3}{|c|}{$\begin{array}{c}\text { Ukupna razina stresa na } \\
\text { poslu odgojitelja }\end{array}$} \\
\cline { 2 - 4 } & $\beta$ & $\mathrm{p}$ & $\mathrm{R}^{2}$ \\
\hline Intenzitet izgaranja na poslu & $\mathbf{0 , 5 4}$ & $\mathbf{0 , 0 1}$ & 0,29 \\
\hline Zadovoljstvo životom & $\mathbf{- 0 , 2 6}$ & $\mathbf{0 , 0 1}$ & 0,07 \\
\hline
\end{tabular}

Legenda: $\beta$-standardizirani regresijski koeficijent, p-statistički značajna povezanost $(p<0,05), \quad R^{2}$-proporcija varijance zavisne varijable objašnjena nezavisnom varijablom 
Osim prikazanih rezultata u skladu s postavIjenim ciljevima, valja istaknuti da su sudionice koje imaju veći broj vlastite djece tjelesno aktivnije $\left(\boldsymbol{\beta}=\mathbf{0 , 2 2}, \mathbf{p}=\mathbf{0 , 0 4}, \mathrm{R}^{2}=0,05\right)$ te da sudionice koje provedu više vremena u putovanju na posao imaju i veću ukupnu razinu stresa na poslu $(\boldsymbol{\beta}=\mathbf{0 , 2 9}$, $\left.\mathbf{p}=\mathbf{0}, \mathbf{0 1}, \mathrm{R}^{2}=0,08\right)$.

\section{RASPRAVA}

Osnovni cilj ovog istraživanja bio je utvrditi razinu tjelesne aktivnosti, intenzitet izgaranja na poslu, ukupnu razinu stresa na poslu te razinu zadovoljstva kod odgojiteljica zaposlenih u Dječjem vrtiću Jarun. Osim toga, cilj istraživanja bio je i ispitati povezanost navedenih varijabli. $U$ istraživanju je od ukupno 84 odgojiteljice sudjelovalo njih 80, što čini 95 \% ukupno zaposlenih odgojiteljica u Dječjem vrtiću Jarun.

Rezultati istraživanja pokazali su da odgojiteljice imaju visoku razinu tjelesne aktivnosti kombinirajući hodanje, umjereni intenzitet ili aktivnost visokog intenziteta. Za procjenu razine tjelesne aktivnosti korištena je skraćena verzija međunarodnog upitnika (IPAQ Short Form) koji se sastoji od pitanja povezanih sa sudjelovanjem u specifičnim aktivnostima svrstanih u tri kategorije: niskog, umjerenog i visokog intenziteta. Ovakvo mjerenje tjelesne aktivnosti je uobičajeno te ga se može pronaći u različitim radovima koji su istraživali razinu tjelesne aktivnosti u dužim ili kraćim verzijama (46-48). Ukupni rezultat na korištenom upitniku o tjelesnoj aktivnosti dobiven je množenjem minuta provedenih $\mathrm{u}$ nekoj od aktivnosti s brojem dana u tjednu te je izražen u metaboličkim jedinicama (MET, eng. Metabolic equivalent of task). Metabolička jedinica predstavlja omjer metaboličke aktivnosti za vrijeme obavljanja nekog rada i metaboličke aktivnosti organizma u stanju mirovanja. S obzirom da je upitnikom ispitana frekvencija i trajanje obavljanja različitih oblika tjelesne aktivnosti i tjelovježbe, jedinica u kojoj je izražen ukupan rezultat ima oblik MET-minuta po tjednu (MET-min/tjedan). Dobivene minute za sve tri kategorije aktivnosti pomnožene su s koeficijentima (3,3 za aktivnost niskog intenziteta, 4 za aktivnost umjerenog intenziteta i 8 za aktivnost visokog intenziteta) kako bi se izračunale MET-minute koje odgovaraju broju kilokalorija za osobu od 60 kilograma.

Istraživanje razine tjelesne aktivnosti na razini hrvatske populacije koje su proveli Jurakić i suradnici (2010.) pokazuje da prosjek ukupne razine tjelesne aktivnosti za slučajno stratificiran uzorak od 1032 sudionika iznosi 58,2 MET-sati/ tjedno, što također ukazuje na visoku razinu tjelesne aktivnosti. Rezultati ovog istraživanja pokazali su da odgojiteljice u Dječjem vrtiću Jarun imaju višu razinu tjelesne aktivnosti (79 MET- sati/ tjedno) od slučajno stratificiranog uzorka. Ovakvi rezultati mogu se objasniti opisom posla odgojiteljica. Naime, odgojiteljice većinu radnog vremena (5,5 sati) provedu u pokretu kroz neposredni rad s djecom. Jedna odgojiteljica u prosjeku brine o 19-30 djece u grupi (ovisno o dobi djece) i samim time su visoko tjelesno aktivne tijekom radnog vremena. Rezultati su pokazali $\mathrm{i}$ da su odgojiteljice koje imaju više rođene djece tjelesno aktivnije, što je logično s obzirom da i njihova djeca zahtijevaju aktivan angažman. Brojna znanstvena istraživanja navedena u ovome radu ukazuju na pozitivnu funkciju koju tjelesna aktivnost može imati u kontekstu psihičkog zdravlja; tjelesna aktivnost povezana je s boljim raspoloženjem, psihičkom dobrobiti i većom razinom samopoštovanja te može imati pozitivan doprinos problemima sa spavanjem. Ljudi koji su u boljoj tjelesnoj kondiciji imaju manje negativnih fizioloških reakcija uzrokovanih stresom te su manje skloni depresivnom raspoloženju. lako je velikim dijelom povećana razina tjelesne aktivnosti uzrokovana specifičnostima posla odgojiteljica, kao i brojem vlastite rođene djece, to ne umanjuje pozitivne učinke tjelesne aktivnosti koji su neophodni za kvalitetan rad s djecom.

Rad s djecom podrazumijeva veliku odgovornost, fokusiranost i koncentraciju te dugoročno može negativno utjecati na zdravlje, tj. može biti uzrokom stresa. Istraživanje provedeno putem skale izvora stresnosti na poslu odgojitelja na 236 odgojitelja dječjih vrtića u Rijeci pokazuje da prosječna opća procjena stresnosti posla odgojitelja (na skali od 0 do3) iznosi 2,36, dok je kod odgojiteljica Dječjeg vrtića Jarun prosječna vrijednost samoprocjene stresnosti posla vrlo slična i iznosi 2,27 , što govori o relativno snažnom doživljaju stresnosti posla (Živčić-Bećirević, Smojver-Ažić, 
2005.). Svega 6,25 \% odgojiteljica smatra da im posao uopće nije stresan ili je malo stresan (procjena 0 i 1), 67,5 \% da je umjereno stresan (procjena 2), a $26,25 \%$ da je jako stresan (procjena 3). Istraživanje u kojem je sudjelovalo 336 odgojiteljica klaster-uzorka dječjih vrtića Splitsko-dalmatinske županije ukazuje na činjenicu da njihove odgojiteljice posao doživljavaju iznimno stresnim (Pavlović, Sindik, 2014.). Uspoređujući podatke s rezultatima na populaciji nastavnika gdje se navodi da oko četvrtina nastavnika doživljava svoj posao visoko stresnim, odgojitelji imaju višu ukupnu razinu stresa (Tomašević et al., 2016.). Prema dobivenim rezultatima moglo bi se zaključiti da je posao odgojitelja djece predškolske dobi stresan, odnosno da ga odgojitelji generalno doživljavaju vrlo stresno, više nego nastavnici koji rade s djecom u školi.

Intenzitet izgaranja dijeli se na tri stupnja: bez izgaranja (prisutni izolirani znakovi stresa), početno izgaranje (ozbiljni znakovi upozorenja zbog trajne izloženosti stresu) i visoki stupanj izgaranja (neophodna pomoć). Rezultati su pokazali da je prva kategorija "bez izgaranja" najzastupljenija, u nju se ubraja 73,75\% ispitanica. $U$ drugu kategoriju početnog izgaranja ubraja se $26,25 \%$ sudionica. U trećoj kategoriji visokog stupnja izgaranja nema ispitanica, odnosno niti jedna odgojiteljica nema ozbiljno izgaranje na poslu. Upitnik intenziteta sagorijevanja na poslu već je upotrebljavan u svrhu mjerenja izgaranja na poslu kod različitih profesija (Friščić, 2007., Kyriacou, 2001., Šogorić, 2018.). Uspoređujući profesiju bankarskih službenika s profesijom odgojitelja predškolske djece vidljivo je kako je direktni rad s klijentima u profesiji bankarskih službenika u poslovnicama zanimanje s velikim predispozicijama za pojavu sindroma izgaranja, dok je izgaranje kod odgojiteljica u Dječjem vrtiću Jarun minimalno (Friščić, 2006.). Izgaranje prisutno kod učitelja predmetne nastave i učitelja razredne nastave je nešto značajnije za razliku od izgaranja odgojiteljica zaposlenih u Dječjem vrtiću Jarun (Kyriacou, 2001.). Rezultati istraživanja profesionalnog izgaranja na medicinskim sestrama/ tehničarima pokazuju da značajan broj medicinskih sestara/tehničara pokazuje ozbiljne znakove izgaranja, čak pola ispitanika nalazi se u početnom ili visokom stupnju izgaranja (Šogorić, 2018.). lako većina odgojiteljica u Dječjem vrtiću Jarun svoj posao doživljava stresnim, to nije rezultiralo ozbiljnim izgaranjem na poslu, za razliku od ostalih profesija poput medicinske struke. Dobivene podatke nezahvalno je uspoređivati s obzirom da na intenzitet izgaranja na poslu utječe puno čimbenika, kao što su okolina i radni uvjeti. $U$ tom smislu, rezultati ovoga istraživanja ukazuju na nešto bolje uvjete rada u Dječjem vrtiću Jarun u usporedbi s drugim profesijama, odnosno radnim mjestima. Uspoređujući ukupnu razinu stresa na poslu i intenzitet izgaranja na poslu, rezultati su pokazali da odgojiteljice u Dječjem vrtiću Jarun s ukupno višom razinom stresa na poslu imaju i viši intenzitet izgaranja na poslu.

$\mathrm{Na}$ skali zadovoljstva životom odgojiteljice u Dječjem vrtiću Jarun svoje zadovoljstvo životom procijenile su nešto nižim od učitelja i nastavnika (Mihaliček, 2011.) te od vrlo velikog broja ispitanika različitih profesija, spola i dobi (Kaliterna $\mathrm{Li}$ povčan, Prizmić-Larsen, 2006., Brkljačić, Kaliterna Lipovčan, 2010.). lako u istraživanju najveći broj odgojiteljica Dječjeg vrtića Jarun, njih 28,75 \% smatra da je zadovoljno životom, njih $20 \%$ je malo nezadovoljno i $12,5 \%$ nezadovoljno što ukazuje na aritmetičku sredinu od 22,4 te je to pokazatelj na skali da su odgojiteljice malo zadovoljne životom. Prema rezultatima istraživanja, na nezadovoljstvo životom statistički značajno je utjecala viša razina stresa na poslu, tj. odgojiteljice koje su doživljavale svoj posao stresnim iskazale su veće nezadovoljstvo životom. Rezultati ukazuju na potrebu edukacije odgojiteljica kako se nositi s izazovima profesije u cilju smanjenja doživljaja stresa na poslu, što bi osim kvalitetnijeg rada s djecom utjecalo i na njihovo veće zadovoljstvo životom.

Uspoređujući razinu tjelesne aktivnosti s varijablama intenziteta izgaranja na poslu, ukupne razine stresa na poslu odgojitelja i zadovoljstva životom, nisu utvrđene statistički značajne povezanosti. S obzirom da je zbog specifičnosti posla većina odgojiteljica visoko tjelesno aktivna, preporuka je da se daljnja istraživanja provedu na većem uzorku i pomoću šire verzije IPAQ upitnika (SF 36) kako bi se preciznije utvrdio utjecaj tjelesne aktivnosti na navedene varijable. Osim tjelesne aktivnosti za daljnja istraživanja preporuka je utvrditi i utjecaj bavljenja tjelovježbom na kvalitetu života odgojiteljica.

lako je istraživanje provedeno u jednom od najvećih vrtića u Gradu Zagrebu, ograničenje 
istraživanja je relativno mali uzorak ispitanika iz samo jednog radnog okruženja, tj. jednog vrtića. Iz navedenog razloga, na rezultate su mogli utjecati međusobni odnosi zaposlenika, zaposlenika i menadžmenta organizacije, odnosno klima i kultura u konkretnom radnom okruženju. Podaci za istraživanje prikupljeni su upitnicima i anketama što kao metoda istraživanja povećava šanse povišenih korelacija kada se ispituju slični i međusobno povezani sadržaji.

\section{ZAKLJUČAK}

Cilj ovog istraživanja bio je utvrditi razinu tjelesne aktivnosti, intenzitet izgaranja na poslu, ukupnu razinu stresa na poslu te razinu zadovoljstva životom odgojiteljica zaposlenih u Dječjem vrtiću Jarun. Uz to, cilj istraživanja bio je i ispitati povezanost navedenih varijabli.

Istraživanje je pokazalo da odgojiteljice zaposlene u Dječjem vrtiću Jarun imaju visoku razinu tjelesne aktivnosti, svoj posao doživljavaju umjereno stresnim, imaju mali intenzitet izgaranja na poslu te da su u prosjeku malo zadovoljne životom. Rezultati pokazuju da, iako odgojiteljice svoj posao doživljavaju stresnim, nije bilo slučajeva ozbiljnog izgaranja. Ipak, odgojiteljice koje su doživljavale višu razinu stresa na poslu imale su i viši intenzitet izgaranja na poslu te su nezadovoljnije životom. Rezultati istraživanja daju smjernice za preventivne mjere u redukciji profesionalnog stresa i edukaciju odgojiteljica usmjerenu na poticanje i održavanje njihove tjelesne aktivnosti na razini koja im pozitivno utječe na zdravlje.

Spoznaje koje donosi ovo istraživanje mogu pomoći u prevenciji stresa, što je vrlo bitno s obzirom da odgojiteljski stres prvenstveno utječe na njihovu kvalitetu rada s djecom, odnose s roditeljima, kolegama i ostalim stručnim suradnicima. Svaki čovjek se različito nosi sa stresnim situacijama u životu, no odabir najučinkovitije metode suočavanja sa stresom je pokazatelj njegove emocionalne kompetentnosti. Također, vrlo je važno educirati i poticati odgojiteljice na kontinuiranu tjelesnu aktivnost i tjelovježbu u slobodno vrijeme kako bi očuvale i unaprijedile fizičko zdravlje.

Rezultati i zaključci istraživanja primjenjivi su samo na konkretno radno okruženje, odnosno
Dječji vrtić Jarun te daju dobar temelj za buduća istraživanja koja bi uključila više vrtića.

\section{LITERATURA}

Ajduković, M., Ajduković, D.: Upitnik intenziteta izgaranja na poslu. Društvo za psihološku pomoć, Zagreb, 1994.

Brkljačić, T., Kaliterna Lipovčan, L.: Zadovoljstvo životom i osjećaj sreće kod studenata. Suvremena psihologija, 13, 2010., 2, 189-200.

Caspersen, C. J., Powell, K. E., Christenson, G. M.: Physical activity, exercise, and physical fitness: definitions and distinctions for health-related research. Public health reports, 100, 1985. , 2,126 .

Clarke-Stewart, A., Lloyd, B.: Daycare (Vol. 30), Harvard University Press, 1993.

Cooper, C. L., Cooper, C. P., Dewe, P. J., O'Driscoll, M. P., O'Driscoll, M. P.: Organizational stress: A review and critique of theory, research, and applications. Sage, 2001.

Craig, C. L., Marshall, A. L., Sjöström, M., Bauman, A. E., Booth, M. L., Ainsworth, B. E., ... \& Oja, P.: International physical activity questionnaire: 12 -country reliability and validity. Medicine \& science in sports \& exercise, 35, 2003., 8, 1381-1395.

Diener, E. D., Emmons, R. A., Larsen, R. J., Griffin, S.: The satisfaction with life scale. Journal of personality assessment, 49, 1985., 1, 71-75.

DV Jarun - Dječji vrtić Jarun. Dostupno na: $<$ http://www.vrtic-jarun.zagreb.hr/>. Pristupljeno 21. srpnja 2019.

Friščić, L.: Čimbenici profesionalnog stresa i izgaranja u radu socijalnih radnika u centru za socijalnu skrb Zagreb. Ljetopis socijalnog rada, 13, 2006., 2, 347-370.

Havelka, M.: Stres i tjelesno zdravlje, U: Havelka M (Ur.) Zdravstvena psihologija. Naklada Slap, Jastrebarsko, 1998., 53-88.

Heimer, S., Jurakić, D., Rakovac, M.: The Republic of Croatia national action plan for health enhancing physical activity, 2011. 
Jurakić, D., Pedišić, Ž., Andrijašević, M.: Physical activity of Croatian population: crosssectional study using International Physical Activity Questionnaire. Croatian medical journal, 50, 2009., 2, 165-173.

Jurakić, D., Pedišić, Ž., Greblo, Z.: Physical activity in different domains and health-related quality of life: a population-based study. Quality of life research, 19, 2010., 9, 1303-1309.

Kelly, A. L., Berthelsen, D. C.: Preschool teachers' experiences of stress. Teaching and Teacher Education, 11, 1995., 4, 345-357.

Klarin, M., Nenadić-Bilan, D.: Stres i izvori stresa odgojiteljskog poziva. Zbornik radova Sveučilište u Zadru, 2004., 4, Stručni odjel za izobrazbu učitelja i odgojitelja predškolske djece.

Kyriacou, C.: Teacher stress: Directions for future research. Educational review, 53, $2001 .$, 1, 27-35.

Lipovčan, L. K., Prizmić-Larsen, Z.: Kvaliteta življenja, životno zadovoljstvo i osjećaj sreće u Hrvatskoj i europskim zemljama. Institut za javne financije, Zaklada Friedrich Ebert, Zagreb, 2006.

Mihaliček, S.: Zadovoljstvo i sreća učitelja. Napredak: časopis za pedagogijsku teoriju i praksu, 152, 2011., 3-4, 389-402.

Misigoj-Durakovic, M., Heimer, S., Gredelj, M., Heimer, Z., Soric, M.: Tjelesna neaktivnost u Republici Hrvatskoj. Acta Medica Croatica, 61, 2007., 3, 253.
Pavlović, Ž., Sindik, J.: Situacijsko suočavanje sa stresom kod odgojitelja. Sigurnost: časopis za sigurnost u radnoj i životnoj okolini, 56, $2014 .$, 3, 187-201.

Program zdravstvene zaštite djece, higijene i pravilne prehrane djece u dječjim vrtićima (Urednički pročišćéni tekst), Narodne novine, br. 105/02. i 55/06.

Sauter, S., Murphy, L., Colligan, M., Swanson, N., Hurrell, J., Scharf, F., Johnston, J.: Stress at work. DHHS (NIOSH) Publication, 99-101, 1999., 1-25.

Šogorić, P.: Usporedba incidencije sindroma profesionalnog izgaranja medicinskih sestara $i$ tehničara na odjelima psihijatrije i objedinjenog bolničkog prijema (Doctoral dissertation), Bjelovar University of Applied Sciences. Department of Nursing, 2018.

Tatalović Vorkapić, S., Lončarić, D.: Posreduje li profesionalno izgaranjE učinke osobina ličnosti na zadovoljstvo životom odgojitelja predškolske djece?. Psihologijske teme, 22, 2013., 3, 431-445.

Tomašević, S., Horvat, G., Leutar, Z.: Intenzitet stresa kod učitelja u osnovnim školama. Socijalne teme: Časopis za pitanja socijalnog rada $i$ srodnih znanosti, 1, 2016., 3, 49-65.

World Health Organization. (2004). Global strategy on diet, physical activity and health.

Živčić-Bećirević, I., Smojver-Ažić, S.: Izvori stresa na poslu odgojitelja u dječjim vrtićima. Psihologijske teme, 14, 2005., 2, 3-13. 


\section{PROFESSIONAL BURNOUT AND PHYSICAL ACTIVITY AMONG TEACHERS AT JARUN KINDERGARTEN}

SUMMARY: Current research dealing with the stress of kindergarten teachers in the workplace is less common than research that focuses on the stress of school teachers and professors. Kindergarten teachers are in constant contact with children and execute work of high responsibility, so this research is justified in attempting to determine the intensity of burnout and the level of physical activity, as well as to prevent any negative events. The study helped to determine the level of physical activity, the intensity of burnout at work, the total level of stress at work, and the level of life satisfaction of the teachers employed at Jarun Kindergarten. We also examined the correlation among the above variables. The sample consisted of 80 female kindergarten teachers, aged 23-61, i.e. 95\% of all teachers employed at Jarun Kindergarten, the second largest kindergarten in the city of Zagreb. The survey was conducted using five questionnaires with a total of 76 questions: Sociodemographic Questionnaire, Burnout Intensity at Work Questionnaire, Educator Job Stress Assessment Scale, International Physical Activity Questionnaire and Satisfaction with Life Scale. Statistical processing is presented through basic descriptive indicators (including the Kolmogorov-Smirnov Distribution Normality Test and Box and Whisker Diagram) and through the distribution of the sample by reference intervals of individual measuring instruments. The correlation between the main variables was tested using a series of linear bivariate regression analyses. The results show that the teachers employed at Jarun Kindergarten have a high level of physical activity, generally find their work moderately stressful, claim a low intensity of burnout at work, and are on average somewhat satisfied with life. Those with a higher total level of stress at work experience a higher intensity of burnout at work and are more dissatisfied with life. The results provide guidance for preventive measures in reducing occupational stress and educating teachers how to build up their physical activity and maintain it at a level that will have a positive effect on their health.

Key words: children, preschool age, stress, exercise, life satisfaction

Preliminary communication Received: 2020-01-08 Accepted: 2020-10-26 